\title{
Earnings Management to Avoid Losses and Earnings Declines in Croatia
}

\begin{abstract}
This paper provides empirical evidence that Croatian companies manage reported earnings to avoid losses and earnings declines. Specifically, we find that the cross-sectional distribution of scaled earnings and changes in earnings show high frequencies of small positive earnings and small increases in earnings while the frequencies of small losses and small decreases in earnings are less frequent. Furthermore, we demonstrate that these discontinuities are likely due to discretionary accruals. We examine the frequency distribution of reported earnings after removing discretionary accruals and find that the cross sectional distributions of non-discretionary scaled earnings shows lower frequencies of small positive earnings and higher frequencies of small negative earnings. Additionally, the cross sectional distribution of non-discretionary change in earnings demonstrates mixed frequencies of non-discretionary changes in earnings. Overall, this paper adds new empirical evidence to the benchmark-beating literature by demonstrating international evidence of earnings management around zero earnings and zero earnings changes benchmarks.
\end{abstract}

Ke y words : Earnings management; Earnings Declines; Earnings Losses; Discretionary Accruals; Earnings frequency distribution

JEL Classifications: C18, F30, G14, G15, G39, M41. 


\section{Introduction}

In recent years, there has been an increasing interest in earnings management around benchmarks (Habib and Hansen, 2008). Previous studies have reported discontinuities at zero in the empirical distributions of earnings in relation to basic benchmarks in both the US and Anglo-Saxon countries (Burgstahler and Dichev, 1997; Burgstahler and Eames, 2003; Beatty, Ke, and Petroni, 2002; Burgstahler and Eames, 2006; Gore, Pope and Singh, 2007; Donelson, Mcinnis, and Mergenthaler, 2013; Burgstahler and Chuk, 2015). However, little attention has been paid to Continental Europe and, in particular, Croatia (Aljinović Barać and Klepo, 2006). Therefore, this study provides an important opportunity to advance the understanding of whether the occurrence of discontinuities within earnings distribution exists beyond the US and the UK. Despite scarce evidence for Europe, Leuz, Nanda and Wysocki (2003) reveal that code-law countries; countries with less developed stock markets, more concentrated ownership and lower disclosure level, all have relatively more prevalent earnings management compared to common-law countries. For instance, Austria, with the same legal origins as Croatia, has the highest level of earnings management in an international comparison of 31 countries (Leuz, Nanda and Wysocki, 2003). On the contrary, common-law countries with a developed stock market, such as the US, have the lowest level of earnings management (Leuz, Nanda and Wysocki, 2003).

Moreover, Aljinović Barać and Klepo (2006) conduct a survey among Croatian auditors and reveal that accounting manipulations in Croatia are fairly significant, primarily with the aim of hiding bad performance, then secondarily to minimise fiscal and political costs and to obtain better terms for banks' crediting, avoiding debt covenants and maximising managers' compensation. The present study expands Aljinović Barać and Klepo’s (2006) study by providing the first empirical findings in Croatia that demonstrates the prevalence of earnings management following Burgstahler and Dichev's (1997) methodology. 
With regards to the accounting standards, since 2005 all consolidated financial statements of publicly traded companies must be prepared in accordance with IFRS; therefore financial statements are prepared under the accruals concept (IASPlus, 2013). For this reason, since managers have more flexibility in changing accruals rather than changing accounting policies, which is more costly, there is a high possibility of earnings manipulation using accruals (Healy, 1985; Watts and Zimmerman, 1978). Therefore, we test whether there is evidence of earnings manipulation specifically using discretionary accruals in Croatia.

The main research objective of this study is to test whether companies in Croatia manage reported earnings to maintain positive earnings as well as positive changes in earnings. The results are based on annual reported earnings of 186 publicly listed Croatian companies, which are collected from Bloomberg database, for the period 2006-2013. The methodology is based on Burgstahler and Dichev (1997) where the frequency distribution is examined with special attention to observations around zero earnings and zero changes in earnings. Moreover, as discussed above since it may be expected that Croatian companies use accruals for earnings manipulation, we examine whether the discontinuities around zero are the result of discretionary accruals. We use both the modified Jones model (Dechow, Sloan and Sweeney, 1995) and the performance-adjusted model (Kothari, Leone and Wasley, 2005) to measure discretionary accruals.

The findings of the study show evidence of high frequency of earnings management around zero earnings and zero earnings changes i.e. high frequency of small positive earnings and small positive earnings changes in relation to last year's earnings. Overall this study contributes to the earnings management literature in two important areas. First, to the best of our knowledge, this paper for the first time empirically investigates and provides evidence on earnings management around earnings benchmarks in Croatia. Second, the findings reveal that the discontinuities in the distribution of earnings around zero (levels and changes) are related to discretionary accruals. 
The rest of this paper is structured as follows. The next section presents a brief review of the literature followed by the development of the hypotheses. Section 4 provides the sample selection procedure and methodology. Section 5 presents the empirical analysis and key findings followed by a final section which concludes this study.

\section{Literature Review}

Over the past two decades, there has been an increasing interest in the research of earnings management. Earnings management incorporates managerial judgement in choosing accounting policies to either convey private information on future earnings and to obtain personal gains, to mislead some stakeholders or to influence contractual outcomes that depend on reported accounting numbers (Healy and Wahlen, 1999; Fields, Lys and Vincent, 2001; Sankar and Subramanyam, 2001; Schipper, 1989).

Prior research has investigated the factors that can create incentives to meet certain benchmarks, such as earnings and analyst earnings forecasts. For example, a considerable amount of 'benchmark-beating' literature discusses cash and equity based CEOs compensation as the motivation to beat earnings benchmarks given that compensation is based directly or indirectly on earnings figures (Healy, 1985; Watts and Zimmerman, 1990; Cheng and Warfield, 2005; Bergstresset and Philippon, 2006; Habib and Hansen, 2008). Furthermore, debt covenants and political costs might also lead to incentives to beat earnings benchmarks given that these may be contingent on earnings (Watts and Zimmerman, 1990; Jones, 1991; Cahan, 1992; DeFond and Jiambalvo, 1994; Key, 1997; Dichev and Skinner, 2002; Latridis and Kadorinis, 2009; Rodríguez Pérez and Hemmen, 2010). Capital market incentives through analysts' earnings forecasts have also been discussed given that analysts' disclosures add value in the capital market (Healy and Palepu, 2001; Dumontier and Raffournier, 2002).

Therefore, due to the high interest in reported earnings, incentives for managing reported earnings in relation to earnings benchmarks are utterly compelling. Thus a considerable amount of 
research on earnings management around benchmarks has been done (Burgstahler and Dichev, 1997; DeGeorge, Patel and Zeckhauser, 1999; Chen et al., 2010) establishing the following three significant benchmarks: earnings levels (to avoid reporting losses), earnings changes (to avoid declines in earnings) and meeting the analysts' forecasts.

Two underlying theories support managers' motives to manipulate accounting figures in order to avoid reporting losses or declines in earnings. First, the prospect theory indicates that investors are willing to invest relative to a particular reference point rather than to the final degree of wealth (Kahneman, and Tversky, 1979). Moreover, this theory confirms that a shift from losses to gains is highly valuable, since investors perceive this as a positive rather than a negative sign. As a result, it is clear that managers are highly motivated to avoid losses as well as negative changes in earnings.

The second theory is transaction theory that is based on the two following assumptions (Burgstahler and Dichev, 1997). First, transaction terms between a company and its stakeholders are affected by earnings information. In addition, companies with higher earnings provide better transaction terms. Furthermore, as Burgstahler and Dichev (1997, p. 123) state "as warehousing, covering and data processing costs are too high, they are likely to induce some stakeholders to focus on simple heuristics as being either nil levels or nil variations of profits in the case of decisionmaking".

Empirical research corroborates the aforementioned theory by providing evidence of earnings management, to avoid negative earnings and earnings decreases. For example, Burgstahler and Dichev (1997) analyse earnings before extraordinary items for the period 1976-1994 in the US setting. They demonstrate unusually high frequencies of small positive earnings and small increases in earnings, whereas small losses and small decreases in earnings have unusually low frequencies. Degeorge, Patel and Zeckhauser (1999) perform a similar analysis using US companies for the period 1974-1996. In their analysis they also include analyst earnings forecasts as an additional earnings threshold to meet. Their results are in line with Burgstahler and Dichev (1997); thus they 
reveal persuasive evidence of earnings management to beat all three earnings benchmarks. Despite this evidence, they imply that scaling earnings could be the reason for the irregularities in distributions. Burgstahler and Eames (2006) examine 25,951 observations in the period from 19862000, they also conclude that US companies' earnings are managed to avoid negative earnings surprises in relation to analysts' forecasts. Further studies in the US that corroborate the interpretation that discontinuities around zero earnings and/or changes in earnings are due to earnings management include Beatty, Ke, and Petroni (2002), Donelson, Mcinnis, and Mergenthaler (2013) and Burgsthahler and Chuk (2015). Together, these studies outline that managers in US companies use accounting discretion to beat the aforementioned earnings benchmarks.

International studies have also been conducted to determine the importance of these earnings benchmarks. However, most of these studies are conducted in developed markets with similarities to the US market. For example, Holland and Ramsay's (2003) analysis of Australian listed companies for the period 1990-2000 report frequencies of earnings consistent with Burgstahler and Dichev's (1997) findings. Furthermore, they extend their research by dividing their sample into small and large firms and as a result, they reveal that the results of earnings management for larger Australian companies are more significant when compared to smaller companies. Gore, Pope and Singh (2007) demonstrate that UK companies engage in earnings manipulation to meet earnings thresholds as well. They also suggest that managing earnings through accruals is related to the discontinuities in earnings distribution. Subsequently, they show that non-discretionary earnings are not discontinuously distributed around benchmarks, whereas earnings distribution is discontinuous. Using an alternative methodology, Peasnell, Pope and Young (2000) also provide evidence of accrual management to avoid earnings losses and earnings declines.

Evidence from Asian countries is consistent with the results of the aforementioned studies. For example, Suda and Shuto (2005) find that Japanese companies manage accruals in order to shift losses and earnings decreases to positive post-managed earnings. Not surprisingly, in line with 
Leuz, Nanda and Wysocki's (2003) findings that common-law countries have less prevalent earnings management than code-law countries, Suda and Shuto's (2005) results demonstrate that Japanese companies engage in earnings management more often than US companies. On the contrary, evidence from Singapore and Thailand refute earnings management to sustain recent performance although there is considerable evidence that Singaporean non-financial and Thai financial companies manage earnings to report positive or zero earnings (Charoenwong and Jiraporn, 2009).

\section{Hypotheses development}

Prior research indicates that earnings quality or the level of earnings management of firms is related to the regulatory, cultural and institutional environment in each country (Hung, 2001; Leuz, Nanda and Wysocki, 2003; Wright et al., 2006; Cabán-García, 2009; Han et al., 2010). Specifically, countries with weak investor protection or regulatory environment have a higher prevalence of earnings management (Leuz, Nanda and Wysocki, 2003; Han et al., 2010). Therefore, earnings management is lower in countries with a higher level of enforcement of the rules, stricter securities regulation, lower ownership concentration and a higher degree of investor protection. Cabán-García (2009), using a sample of European firms, finds that each country's security regulations has an impact on earnings quality, and this is only slightly alleviated by cross-listing in countries with stricter regulations. The level of tolerance to earnings management also differs in relation to the environment. For example, individuals from stakeholder-oriented institutional backgrounds are less accepting of earnings management than those from shareholder-oriented institutional backgrounds (Geiger and Smith, 2010).

The Croatian market has a different institutional setting than Anglo-Saxon countries. Croatia is part of the Middle and Eastern European countries in transition; hence, it is a relatively young financial market and it has a bank-oriented rather than a market-oriented economy (Cingula, Ređep and Klačmer, 2003; Seba Grubišić, 2013). Moreover, since Croatian taxation and accounting rules 
are aligned with macroeconomics objectives (Aljinović Barać and Klepo, 2006) it is evident that financial statements are not prepared with the intention of reducing information asymmetry as is the case in the US. In addition, there can be no doubt that tax authorities, creditors and investors are the most important targets for earnings manipulation (Aljinović Barać and Klepo, 2006). Prior research indicates that earnings management in countries in which companies are financed mostly by debt (e.g. France) are directly linked to contractual debt costs and the effective tax rate (Othman and Zeghal, 2006) as opposed to Anglo-American firms that rely more on the capital markets. Hence, it can be argued that Croatian managers have incentives to hide reported losses due to an increase in transaction costs, if they report these losses (Burgstahler and Dichev, 1997). Additionally, according to Leuz, Nanda and Wysocki (2003), European companies evidently show a greater magnitude of earnings management due to loss avoidance. The survey results of Aljinović Barać and Klepo (2006) confirm Leuz, Nanda and Wysocki’s (2003) findings and conclude that hiding bad performance is one of the main reasons for earnings manipulation in Croatia. Therefore, the first hypothesis is the following:

H1: Earnings are managed to avoid losses

Due to the institutional setting of the Croatian market, it is very likely that companies engage in earnings management to avoid debt covenant violation (Dichev and Skinner, 2002). In other words, if companies' performance begins to decrease, the possibility of engaging in earnings manipulation is higher (Dichev and Skinner, 2002), most likely to avoid violating their debt covenants. Therefore, it seems reasonable to expect that Croatian companies manage reported earnings to sustain previous year's earnings. For this reason, the following hypothesis is addressed:

H2: Earnings are managed to avoid declines in relation to prior year's earnings

Additionally, all consolidated financial statements of Croatian publicly listed companies from 2005 are prepared under the accruals concept of IFRSs (IASPlus, 2013). Prior research indicates that discretionary accruals are used as a common method for earnings manipulations (Jones, 1991; 
DeFond and Jiambalvo, 1994) and are less costly than changing accounting policies (Watts and Zimmerman, 1978; Healy, 1985). In addition, discretionary accruals are incorporated within the reported earnings, and cause discontinuities in earnings distribution, hence it is expected that their removal will minimise discontinuities (Jones, 1991; Gore, Pope and Singh, 2007). Therefore we test the following hypotheses:

H3: Non-discretionary earnings do not exhibit a discontinuity around zero

H4: Non-discretionary changes in earnings do not exhibit a discontinuity around zero

We do not hypothesise or test earnings management in relation to the analysts' earnings forecasts benchmarks, given that Croatia's market is less developed and analyst information is not regarded as significant as the other earnings benchmarks (Aljinović Barać and Klepo, 2006).

\section{Sample Selection and Methodology}

\subsection{Sample Selection}

For the purpose of this analysis, available data of annual reported earnings of Croatian listed companies in 2013 for the period 2005-2013 is collected from the Bloomberg database. The initial sample comprised of 264 publicly listed companies on Zagreb Stock Exchange. The sample is reduced by eliminating all the companies within the financial industry. Moreover, we require companies to have announced financial statements at least three years in a row for the purpose of discretionary accrual measurement. The final sample consists of 186 companies over the period 2006-2013. ${ }^{1}$

\subsection{Methodology}

This study tests whether companies in Croatia manage reported earnings to maintain positive earnings and/or positive changes in earnings. We use the frequency distribution methodology as set out in the Burgstahler and Dichev (1997) study. Specifically, we examine the frequency distribution of $E_{t}$ (Earnings in year $t$ ) and $\Delta E_{t}$ (Change in earnings between year $t$ and the previous year $\left.t-1\right) . E_{t}$

\footnotetext{
${ }^{1}$ Data in year 2005 is used to estimate discretionary accruals and therefore is not part of the sample period.
} 
variables are scaled by opening total assets in year $\mathrm{t}$ and $\Delta \mathrm{E}_{\mathrm{t}}$ variables are scaled by opening total assets in year $\mathrm{t}-1$. The opening total assets is chosen as the scaling factor rather than market value of equity given that the stock market in Croatia is less developed than in the US and UK. Histograms of the pooled cross-sectional empirical distribution of the scaled level of earnings and the scaled earnings changes are provided for all available firms in the sample in the years 20062013 for the earnings variable and 2007-2013 for the earnings change variable. ${ }^{2}$ As a result, the documented distributions reveal if earnings levels and changes are distributed with discontinuities around zero.

Moreover, the review of the literature has already revealed that the use of discretionary accruals is related to earnings management to beat earnings benchmarks and it is expected that their removal will minimise discontinuities (Gore, Pope and Singh, 2007). We calculate discretionary accruals using both the modified Jones model (Dechow, Sloan and Sweeney, 1995) and the performance-adjusted model (Kothari, Leone and Wasley, 2005).

We calculate discretionary accruals using the modified Jones model (Dechow, Sloan and Sweeney, 1995). First, we estimate the following regression:

$$
\mathrm{TA}_{\mathrm{it}}=\alpha_{1}\left(1 / \mathrm{A}_{\mathrm{it}-1}\right)+\alpha_{2}\left(\Delta \mathrm{REV}_{\mathrm{it}}\right)+\alpha_{3}\left(\mathrm{PPE}_{\mathrm{it}}\right)+\varepsilon_{\mathrm{it}}
$$

The regression is run on an annual basis, where,

$\mathrm{TA}_{\mathrm{it}}=$ total accruals for firm $\mathrm{i}$ in year $\mathrm{t}$ defined as current assets less cash minus current liabilities less short-term debt, excluding depreciation ;

$\mathrm{A}_{\mathrm{it}-1}=$ total assets for firm $\mathrm{i}$ in $\mathrm{t}-1$;

$\Delta \mathrm{REV}_{\mathrm{it}}=$ revenues for firm $\mathrm{i}$ in year $\mathrm{t}$ less revenues in year $\mathrm{t}-1$ scaled by total assets at $\mathrm{t}-1$;

$\Delta \mathrm{REC}_{\mathrm{it}}=$ net receivables for firm $\mathrm{i}$ in year $\mathrm{t}$ less net receivables in year $\mathrm{t}-1$ scaled by total assets at $\mathrm{t}-1$;

$\mathrm{PPE}_{\mathrm{it}}=$ gross property plant and equipment for firm $\mathrm{i}$ in year $\mathrm{t}$ scaled by total assets at $\mathrm{t}-1$;

\footnotetext{
${ }^{2}$ Outliers are eliminated in the distributional histograms.
} 
$\varepsilon_{\mathrm{it}},=$ normally distributed error term .

Using the firm specific coefficients from the above regression, $\widehat{\alpha}_{1}, \widehat{\alpha}_{2}, \widehat{\alpha}_{3}$, we then estimate the non-discretionary accruals as:

$$
\text { MJ_NDA } A_{i t}=\widehat{\alpha}_{1}\left(1 / \mathrm{A}_{\mathrm{it}-1}\right)+\widehat{\alpha}_{2}\left(\Delta \mathrm{REV}_{\mathrm{it}}-\Delta \mathrm{REC}_{\mathrm{it}}\right)+\widehat{\alpha}_{3}\left(\mathrm{PPE}_{\mathrm{it}}\right),
$$

where, MJ_NDA $A_{i t}=$ non-discretionary accruals for firm $\mathrm{i}$ in year $\mathrm{t}$, using the modified Jones methodology. All other variables are as previously defined.

We also employ the performance-adjusted model (Kothari, Leone and Wasley, 2005) to calculate discretionary accruals. First, we estimate the following regression:

$$
\mathrm{TA}_{\mathrm{it}}=\alpha_{0}+\alpha_{1}\left(1 / \mathrm{A}_{\mathrm{it}-1}\right)+\alpha_{2}\left(\Delta \mathrm{REV}_{\mathrm{it}}\right)+\alpha_{3}\left(\mathrm{PPE}_{\mathrm{it}}\right)+\alpha_{4} \mathrm{ROA}_{\mathrm{it}}+\varepsilon_{\mathrm{it}},
$$

where $\mathrm{ROA}_{\mathrm{it}}=$ return on assets for firm $\mathrm{i}$ in year $\mathrm{t}$, measured as net income divided by total assets. All other variables are as previously defined. The regression is run on an annual basis in line with Kothari et al. (2005).

Using the firm specific coefficients from the above regression, $\widehat{\alpha}_{0}, \widehat{\alpha}_{1}, \widehat{\alpha}_{2}, \widehat{\alpha}_{3}, \widehat{\alpha}_{4}$, we then estimate the non-discretionary accruals as:

$$
\text { PA_NDA } i t=\widehat{\alpha}_{0}+\widehat{\alpha}_{1}\left(1 / \mathrm{A}_{\mathrm{it}-1}\right)+\widehat{\alpha}_{2} \Delta \mathrm{REV}_{\mathrm{it}}+\widehat{\alpha}_{3} \mathrm{PPE}_{\mathrm{it}}+\widehat{\alpha}_{4} \mathrm{ROA}_{\mathrm{it}}+\mathrm{v}_{\mathrm{it}},
$$

where, PA_NDA $\mathrm{it}_{\mathrm{it}}=$ non-discretionary accruals of firm $\mathrm{i}$ in year $\mathrm{t}$, using the performance-adjusted methodology and all other variables are as previously defined.

Discretionary accruals are then measured as follows:

$$
\begin{aligned}
& \text { MJ_DA } A_{i t}=T_{i t}-M J \_N D A_{i t} \text {, } \\
& \text { PA_DA } A_{i t}=\mathrm{TA}_{i t}-\mathrm{PA} \_\mathrm{NDA}_{i t} \text {, }
\end{aligned}
$$

where,

MJ_DA $A_{i t}=$ discretionary accruals for firm $\mathrm{i}$ in year $\mathrm{t}$, using the modified Jones model;

PA_DA $A_{i t}=$ discretionary accruals for firm $\mathrm{i}$ in year $\mathrm{t}$, using the performance-adjusted model; All other variables are as previously defined. 
We then calculate earnings and change in earnings before discretionary accruals by subtracting discretionary accruals from earnings in each year t. Therefore, we provide frequency distributions for the following six variables: ${ }^{3}$

$\mathrm{E}_{\mathrm{t}}=$ Earnings scaled by opening total assets in year $\mathrm{t}$;

MJ_NDE $\mathrm{t}_{\mathrm{t}}=$ Non-discretionary earnings, scaled by opening total assets in year $\mathrm{t}$, measured as earnings in year $t$ less discretionary accruals in year $t$, estimated with the modified Jones model in year t;

PA_NDE $\mathrm{t}_{\mathrm{t}}=$ Non-discretionary earnings, scaled by opening total assets in year $t$, measured as earnings in year $\mathrm{t}$ less discretionary accruals in year $\mathrm{t}$, estimated with the performance-adjusted model in year t;

$\Delta \mathrm{E}_{\mathrm{t}}=$ Change in earnings scaled by opening total assets in year $\mathrm{t}-1$;

MJ_ND $\Delta \mathrm{E}_{\mathrm{t}}=$ Non-discretionary change in earnings scaled by opening total assets in year t-1 measured as change in earnings less discretionary accruals, estimated with the modified Jones model in year t-1;

PA_ND $\Delta E_{t}=$ Non-discretionary change in earnings scaled by opening total assets in year t-1 measured as change in earnings less discretionary accruals, estimated with the performanceadjusted model in year $\mathrm{t}-1$.

The statistical significance of the hypotheses is tested by using a method similar to that used in Burgstahler and Dichev (1997). Specifically, under the null hypothesis of no deviations from a normal distribution, the cross sectional distribution of earnings changes and earnings levels is relatively smooth. We present the frequency distribution of the variables across intervals of $E_{t}$ or $\Delta \mathrm{E}_{\mathrm{t}}$ and test that the distribution is smooth using standardised differences. This standardised difference is the difference between the actual number of observations and the expected number of observations within an interval divided by the estimated standard deviation of the difference. The

\footnotetext{
${ }^{3}$ We eliminate the i subscript for simplicity.
} 
expected number of observations in an interval is equal to the average of the two adjacent intervals. This standardised difference will approximate a normal distribution with mean 0 and standard deviation 1. In order to test our hypotheses, we examine the intervals around the zero benchmark and test whether these intervals have a statistically significant positive (actual observations greater than what is expected) or negative (actual observations lower than expected) standardised difference. Specifically, we focus on the interval immediately to the right of zero, which we expect to have a higher number of observations than would be expected in a normal distribution; as well as the interval immediately to the left of zero, which we expect to have a lower number of observations than expected in a normal distribution.

\section{Empirical Results}

\subsection{Descriptive Statistics}

Table 1 presents the descriptive statistics for the earnings level sample (Panel A) and the earnings change sample (Panel B). Note that both earnings variables are scaled by beginning total assets in year $\mathrm{t}$ for the earnings level sample and in year $\mathrm{t}-1$ for the earnings change sample. For the earnings level sample (Panel A), we find that the mean is negative for all the earnings level variables. On the contrary, the median for $\mathrm{E}_{\mathrm{t}}$ is 0.003 while medians for non-discretionary earnings estimated with the modified Jones model in year $\mathrm{t}\left(\mathrm{MJ} \_\mathrm{NDE}_{\mathrm{t}}\right)$ and the non-discretionary earnings estimated with the performance-adjusted model in year $t\left(\mathrm{PA}_{-} \mathrm{NDE}_{\mathrm{t}}\right)$ are -0.036 and -0.024 , respectively. ${ }^{4}$ The standard deviation of both non-discretionary earnings is higher than the standard deviation of $E_{t}$. Thus it is clear that MJ_NDE $E_{t}$ and PA_NDE in the sample period. The Min (Max) value for the $E_{t}$ is -0.538 (1.493) while for MJ_NDE $E_{t}$ it is $8.806(16.670)$ and for PA_NDE $\mathrm{t}$ it is $-8.116(16.677)$.

((INSERT TABLE 1 ABOUT HERE))

\footnotetext{
${ }^{4}$ The non-discretionary variables, MJ_NDE and PA_NDE_t are residuals from regressions (1) and (2). To check for the normality of the residuals, we estimate the Shapiro-Wilk statistic for all regressions and find the assumption of normality holds.
} 
Panel B provides descriptive statistics for the earnings change sample. The number of observations is lower than the earnings level sample due to the calculation requirements. Moreover, mean (0.002) and median (0.000) for the change in earnings scaled by opening total assets in year $\mathrm{t}$ $1\left(\Delta \mathrm{E}_{\mathrm{t}}\right)$ are close, hence, it seems that distribution of change in earnings scaled by opening total assets is normal. With respect to non-discretionary earnings changes estimated with the modified Jones model $\left(\mathrm{MJ} \_\mathrm{ND} \Delta \mathrm{E}_{\mathrm{t}}\right)$, both mean and median are positive, while, on the contrary, both are negative when non-discretionary earnings changes are estimated using the performance-adjusted model (PA_ND $\left.\Delta \mathrm{E}_{t}\right)$, possibly due to controlling for firm performance in the second methodology. In addition, it is evident that $\mathrm{MJ} \_\mathrm{ND} \Delta \mathrm{E}_{\mathrm{t}}$ and $\mathrm{PA} \_\mathrm{ND} \Delta \mathrm{E}_{\mathrm{t}}$ data are scattered more widely than $\Delta \mathrm{Et}$ considering the standard deviations (0.865 and 0.939 versus 0.136$)$. Also, the Min (Max) values reveal similar differences between the earnings sample and earnings change sample, i.e. Min (Max) for $\Delta \mathrm{E}_{\mathrm{t}}$ is $-1.106(1.681)$, for $\mathrm{MJ} \_\mathrm{ND} \Delta \mathrm{E}_{\mathrm{t}}$ is -16.463 (16.716) and for PA_ND $\Delta \mathrm{E}_{\mathrm{t}}$ is -16.455 (16.723).

In summary, from the descriptive statistics it is obvious that the earnings level sample differs from the earnings change sample of Croatian companies in the period 2006-2013. More importantly, standard deviation of both earnings and earnings change samples reveal that nondiscretionary earnings and non-discretionary earnings change variables are scattered more widely compared to earnings and earnings changes variables suggesting that earnings discretion aims to smooth earnings figures. Similar conclusions are made when one compares minimum and maximum values of both earnings variables

The next sub-sections present and discuss the findings which emerged from the statistical analysis of the sample data during the 2006-2013 period. In addition, consistent with previous research, the evidence of earnings management around earnings benchmarks is presented as follows: firstly, earnings and non-discretionary earnings distributions are provided followed by the earnings changes and non-discretionary earnings changes distributions. 


\subsection{Earnings management to avoid losses}

Figure 1 presents the results of the first hypothesis test (managers manage earnings to avoid losses). More specifically, figure 1 presents the distribution of annual net income scaled by opening total asset in year t during the period 2006-2013. Note Figures 1-3 report earnings level variables on interval basis of a width of 0.005 , in a range from -0.14 to 0.14 . Also note that if the first hypothesis is true (i.e. earnings are managed to avoid losses) it predicts discontinuities in the distribution of scaled earnings around zero earnings.

Figure 1 shows a bell-shaped distribution with a single peak. It is apparent from the histogram that there are irregularities around zero which is consistent with the predictions of the first hypothesis. Additionally, there are a relatively small number of observations at zero and less than zero whereas there are a large number of observations slightly greater than zero. Furthermore, Burgstahler and Dichev's (1997) statistical test reveal the significance of these results. Specifically, the standardised difference for the first interval on the right-hand side of zero (between 0 and 0.005 ) is -6.383 , indicating that there are significantly less observations than expected at the $1 \%$ level. The standardised difference for the interval to the right of that (between 0.005 and 0.010 ) is 9.774 indicating a higher than expected number of observations, while the interval immediately to the left of zero (-0.005 to 0$)$ is 0.249 which is not significantly different from what is expected under a normal distribution. These results provide evidence that earnings are shifted from losses or zero earnings to positive earnings. However, surprisingly, firms seem to shift not to the immediate right of zero but towards more positive earnings above 0.005 , possibly to avoid being close to the zero earnings benchmark.

\section{((INSERT FIGURE 1 ABOUT HERE))}

Figures 2 and 3 present the results of the third hypothesis test (non-discretionary earnings do not exhibit a discontinuity around zero). Figure 2 shows the distribution of annual non-discretionary earnings scaled by opening total assets, in time $t$, estimated with the modified Jones model during 
the period 2006-2013 $\left(\mathrm{MJ}_{-} \mathrm{NDE}_{\mathrm{t}}\right)$. Note that if hypothesis 3 is true, it is expected that the removal of discretionary accruals from earnings will minimise discontinuities around zero if earnings are manipulated.

Figure 2 results reveal that non-discretionary earnings are spread more widely than scaled earnings. Consistently with the third hypothesis predictions, discontinuities around zero disappear due to removal of discretionary accruals. Therefore, the distribution of $\mathrm{MJ}_{-} \mathrm{NDE}_{\mathrm{t}}$ is relatively smooth. Furthermore, the standardised difference in the intervals around zero does not show any significance. For example, the standardised difference in the interval to the right of zero (0.000 to $0.005)$ is -0.894 while that of the interval to the left of zero $(-0.005$ to 0.000$)$ is 0.319 . Interestingly, this histogram shows higher frequencies of negative earnings rather than frequencies of positive earnings. In addition, if one compares Figures 2 and 1, it is apparent the lower frequency of small positive earnings because these earnings figures may be free from managerial discretion.

\section{((INSERT FIGURE 2 ABOUT HERE))}

As already mentioned, Figure 3 also presents the results of the third hypothesis test using an alternative methodology. More specifically Figure 3 presents the distribution of annual nondiscretionary earnings scaled by opening total assets, in year $t$, estimated with the performanceadjusted model during the period 2006-2013 (PA_NDE $)$.

\section{((INSERT FIGURE 3 ABOUT HERE))}

Figure 3 results also reveal that PA_NDE $\mathrm{t}$ are spread more widely than scaled earnings. Not surprisingly, the distribution of PA_NDE $\mathrm{t}_{\mathrm{t}}$ is consistent with the predictions of the third hypothesis, that the removal of discretionary accruals from scaled earnings will minimise discontinuities around zero, hence, it is relatively smooth. The standardised differences also do not show any significance. Specifically, the standardised difference for the interval to the right of zero (0.000 to 0.005$)$ is 0.268 and for the interval to the left of zero $(-0.005$ to 0.000$)$ is 0.000 . Moreover, Figure 3 similarly to Figure 2 reveals higher frequencies of negative earnings rather than positive earnings. More 
importantly Figure 3 (similarly to Figure 2) when compared to figure 1 exposes the significant lower frequency of small positive earnings because these earnings figures may be free from managerial discretion.

Overall, these results indicate that earnings management due to loss avoidance is prevalent in Croatian companies. Moreover, a comparison of the scaled earnings and two non-discretionary scaled earnings distributions reveals that managers in Croatia use their discretion for the enhancement of the reported earnings. The presented findings in this subsection are consistent with the existing research of earnings management to avoid losses.

\subsection{Earnings management to avoid declines in profit}

This subsection discusses the evidence of earnings management to avoid declines in earnings. Histograms are constructed to present the frequency distributions in the earnings change sample. These frequency distributions are presented in figures 4,5 and 6 . Note that these figures present earnings change variables on interval basis of a width of 0.0025 in a range from -0.075 to 0.075 .

Figure 4 presents the results of the second hypothesis test (managers manage earnings to avoid earnings declines). More specifically figure 4 displays the distribution of the change in annual net income scaled by opening total assets, in year $\mathrm{t}-1$, during the period $2007-2013\left(\Delta \mathrm{E}_{\mathrm{t}}\right)$. If the second hypothesis is true, it predicts discontinuities in the distribution of the scaled earnings changes around zero earnings changes. In other words hypothesis 2 predicts high frequencies of small positive earnings changes and low frequencies of small negative earnings changes on the distribution of scaled changes in earnings $\left(\Delta \mathrm{E}_{\mathrm{t}}\right)$.

Figure 4 presents a single peaked bell-shaped distribution. It is obvious that there are high frequencies of small positive earnings changes whereas the small negative earnings changes are less frequent. Such findings are consistent with the predictions of the second hypothesis. Furthermore, statistical significance has been confirmed by Burgstahler and Dichev's (1997) statistical test. The standardised difference for the interval to the right of zero $(0.000$ to 0.0025$)$ is 4.763 , which 
indicates a significantly higher than expected number of observations; whereas the standardised difference for the interval to the left of zero $(-0.0025$ to 0.000$)$ is -5.504 , indicating a significantly lower than expected number of observations. Additionally, the second interval to the right of zero (0.0025 to 0.005$)$ has a standardised difference of 4.340 . These results confirm that companies in Croatia do manage earnings to avoid decreases in earnings compared to prior year earnings.

\section{((INSERT FIGURE 4 ABOUT HERE))}

As explained earlier, it is expected that the removal of discretionary accruals from scaled change in earnings will minimise discontinuities around zero. This implies that non-discretionary changes in earnings are not expected to exhibit discontinuity around zero (hypothesis 4). Hence, the two distributions of non-discretionary change in earnings are presented in Figures 5 and 6 in order to test hypothesis 4 .

More specifically, Figure 5 presents the distribution of non-discretionary earnings changes scaled by opening lagged total assets estimated with the Modified Jones model, in year $\mathrm{t}-1$, for the period 2007-2013 (MJ_ND $\left.\Delta \mathrm{E}_{\mathrm{t}}\right)$.

\section{((INSERT FIGURE 5 ABOUT HERE))}

Figure 5 presents clear evidence that non-discretionary scaled changes in earnings are spread differently from scaled changes in earnings. In addition, the distribution is not bell shaped nor single peaked as is the distribution of scaled change in earnings (see Figure 4). The standardised differences in the intervals around zero reveal similar results. Specifically, the standardised difference for the interval to the right of zero $(0.000$ to 0.0025$)$ is 0.311 and that of the interval to the left of zero $(-0.0025$ to 0.000$)$ is -0.207 , which are not statistically significant. These findings are consistent with the predictions of the fourth hypothesis which suggest that discontinuities around zero earnings changes disappear due to the removal of discretionary accruals. Not surprisingly, this histogram shows mixed frequencies of non-discretionary changes in earnings. 
Figure 6 shows the distribution of annual non-discretionary changes in earnings scaled by opening lagged total assets estimated with the performance-adjusted model, in year $\mathrm{t}-1$, during the period 2007-2013 (PA_ND $\left.\Delta \mathrm{E}_{\mathrm{t}}\right)$.

Figure 6 similar to figure 5 suggests that the distribution of PA_ND $\Delta \mathrm{E}_{t}$ is different than that of $\Delta \mathrm{E}_{\mathrm{t}}$ (see Figure 4). Furthermore, this multimodal distribution of PA_ND $\Delta \mathrm{E}_{\mathrm{t}}$ is in line with the expectation of hypothesis 4 that the removal of the discretionary accruals from scaled change in earnings will reduce the frequency of small positive earnings changes in the distribution. In addition, Figure 6 similar to Figure 5 demonstrates mixed frequencies of non-discretionary changes in earnings. Standardised differences as in the prior graph (Figure 5) do not reveal significant differences from normal distribution around zero. The standardised difference of the interval to the right of zero $(0.000$ to 0.0025$)$ is -0.052 and that of the interval to the left of zero ( -0.0025 to 0.000$)$ is -0.026 .

To sum up, the results from this subsection illustrate that earnings management to avoid declines in profit is prevalent in Croatian companies. When the frequency distribution of changes in annual net income scaled by opening lagged total assets is compared to two non-discretionary scaled changes in earnings distributions it is evident that Croatian managers use their discretion to beat the benchmark of previous year's earnings. Therefore, findings in this section are consistent with the existing research on earnings management in order to avoid earnings declines from prior year earnings.

((INSERT FIGURE 6 ABOUT HERE)

\section{Conclusion}

In this study, the main objective is to assess whether companies in Croatia manage reported earnings. Following this, we provide evidence of the frequency of earnings management around two benchmarks, namely zero earnings and maintaining current earnings in relation to last year's earnings. The analysis is performed on 186 companies with data over the period 2006-2013 using 
Burgstahler and Dichev's (1997) distributional approach. Furthermore, we expect that removing discretionary accruals would reduce irregularities within cross sectional frequency distributions. The most obvious finding to emerge from this study is that managers in Croatian companies manipulate earnings to avoid losses as well as to sustain previous earnings levels. In addition, the statistical tests confirm the significance of the overall results. Furthermore, upon removal of discretionary accruals from reported earnings, these discontinuities are reduced, providing evidence of accrual manipulation in Croatia. Taken together, these results suggest a prevalence of earnings management in Croatia using discretionary accruals.

The findings in this paper are subject of a number of important limitations that need to be considered. As stated in existing literature, this approach does not consider the background in which earnings management has been achieved (Holland and Ramsay, 2003). In addition, the period that was analysed includes a prolonged financial crisis. Secondly, due to the small sample of companies, the regression analysis for the calculation of non-discretionary accruals was performed by years rather than industries. Moreover, the distributional approach does not consider incentives for earnings management to reach benchmarks (Holland and Ramsay, 2003).

This study has identified some questions in need of further investigation. It would be interesting to assess the steps that companies use for earnings enhancements to reach benchmarks. Future research might investigate the extent and the scope of earnings management in Croatia in different industries. Another possible area of future research would be to investigate why companies manage earnings to beat benchmarks. Hence, further research needs to examine more closely the links between earnings management and incentives. 


\section{References}

Aljinović Barać, Ž. and Klepo, T. (2006) 'Features of accounts manipulations in Croatia', Zbornik radova Ekonomskog fakulteta u Rijeci, 24(2): 273-289.

Ayers, B.C., Jiang, J. and Yeung, P.E. (2006), 'Discretionary Accruals and Earnings Management: An Analysis of Pseudo Earnings Targets', The Accounting Review, 81(3): 617-652.

Beatty, A., Ke, B. and Petroni, K. (2002), 'Earnings management to avoid earnings declines across publicly and privately held banks', The Accounting Review, 77(3): 547-570.

Bergstresset, D. and Philippon, T. (2006) 'CEO incentives and earnings management', Journal of Financial Economics, 80: 511-529.

Burgstahler, D. and Dichev, I. (1997) 'Earnings management to avoid earnings decreases and losses', Journal of Accounting and Economics, 24: 99-126.

Burgstahler, D. and Eames, M.J. (2003) 'Earnings management to avoid losses and earnings decreases: Are analysts fooled?' Contemporary Accounting Research 20(2): 253-294.

Burgstahler, D. and Eames, M.J. (2006) 'Management of Earnings and Analysts' Forecast to Achieve Zero and Small Positive Earnings Surprises', Journal of Business, Finance and Accounting, 33: 633-652.

Burgstahler, D. and Chuk, E. (2015) 'Do scaling and selection explain earnings discontinuities?' Journal of Accounting and Economics, 60 (1): 168-186.

Cabán-García, M.T. (2009) 'The impact of securities regulation on the earnings properties of European cross-listed firms', The International Journal of Accounting, 44(3): 279-304.

Cahan, S.F. (1992) 'The Effect of Antitrust Investigations on Discretionary Accruals', The Accounting Review, 67(1): 77-95.

Charoenwong, C. and Jiraporn, P. (2009) 'Earnings management to exceed thresholds: Evidence from Singapore and Thailand', Journal of Multinational Financial Management, 19: 221-236.

Chen, S.K., Bing-Xuan, L., Wang, Y. and Liansheng, W. (2010) 'The frequency and magnitude of earnings management: Time - series and multi -threshold comparisons', International Review of Economics and Finance, 19: 671-685.

Cheng, Q. and Warfield, T.D. (2005) 'Equity Incentives and Earnings management', The Accounting Review, 80(2): 441-476.

Cingula, M., Ređep, M. and Klačmer, M. (2003) 'Some actual aspects of Croatian capital market development', Journal of International research Publication, 3.

Dechow, P.M., Sloan, R.G. and Sweeney, A.P. (1995) 'Detecting Earnings Management', The Accounting Review, 70(2): 193-225. 
DeFond, M.L. and Jiambalvo, J. (1994), 'Debt covenant violation and manipulation of accruals', Journal of Accounting and Economics, 17: 145-176.

Degeorge, F., Patel, J. and Zeckhauser, R. (1999) 'Earnings Management to Exceed Thresholds', Journal of Business, 72(1): 1-33.

Dichev, I.D. and Skinner, D.J. (2002) 'Large - Sample Evidence on the Debt Covenant Hypothesis', Journal of Accounting Research, 40(4): 1091-1123.

Donelson, D.C., Mcinnis, J.M. and Mergenthaler, R.D. (2013) 'Discontinuities and earnings management: Evidence from restatements related to securities litigation', Contemporary Accounting Research, 30(1): 242-268.

Dumontier, P. and Raffournier, B. (2002) 'Accounting and capital markets: a survey of the European evidence', The European Accounting Review, 11(1): 119-151.

Fields, T.D., Lys, T.Z. and Vincent, L. (2001) 'Empirical research on accounting choice', Journal of Accounting and Economics, 31: 255-307.

Geiger, M. \& Smith, J.V.D.L. 2010, "The Effect of Institutional and Cultural Factors on the Perceptions of Earnings Management", Journal of International Accounting Research, 9 (2): 21-43.

Gore, P., Pope, P.F. and Singh, A.K. (2007) 'Earnings management and the distribution of earnings relative to targets: UK evidence', Accounting and Business Research, 37(2): 123-150.

Habib, A. and Hansen, J.C. (2008) 'Target Shooting: Review of Earnings Management Around Earnings Benchmarks', Journal of Accounting Literature, 27: 25-70.

Han, S., Kang, T., Salter, S., \& Yoo, Y. (2010) 'A cross-country study on the effects of national culture on earnings management', Journal of International Business Studies, 41(1): 123-141.

Hansen, J.C. (2010) 'The effect of alternative goals on earnings management studies: An earnings benchmark examination', Journal of Accounting and Public Policy, 29(5): 459-480.

Healy, P.M. (1985) 'The effect of bonus schemes on accounting decisions', Journal of Accounting and Economics, 7: 85-107.

Healy, P.M. and Palepu, K.G. (2001) 'Information asymmetry, corporate disclosure, and the capital markets: A review of the empirical disclosure literature', Journal of Accounting and Economics, 31: 405-440.

Healy, P.M. and Wahlen, J.M. (1999) 'A review of the earnings management literature and its implications for standard setting', Accounting Horizons, 13(4): 365-383.

Holland, D. and Ramsay, A. (2003) 'Do Australian companies manage earnings to meet simple earnings benchmarks?', Accounting and Finance, 43: 41-62.

IASPlus (2013) Financial Reporting Framework in Croatia. Available at: http://www.iasplus.com/en/jurisdictions/europe/croatia (Accessed: 23 March 2014). 
Hung, M. (2001) 'Accounting standards and value relevance of financial statements: An international analysis', Journal of Accounting and Economics, 30(3): 401-420.

Jones, J.J. (1991) 'Earnings Management During Import Relief Investigations', Journal of Accounting Research, 29(2): 193-238.

Kahneman, D. and Tversky, A. (1979) 'Prospect Theory: An Analysis of Decision under Risk', Econometrica, 47(2): 263-291.

Key, K.G. (1997) 'Political cost incentives for earnings management in the cable television industry', Journal of Accounting and Economics, 23: 309-337.

Kothari, S.P., Leone, A.J. and Wasley, C.E. (2005) 'Performance matched discretionary accrual measures', Journal of Accounting and Economics, 39: 163-197.

Latridis, G. and Kadorinis, G. (2009) 'Earnings management and firm financial motives: A financial investigation of UK listed companies', International Review of Financial Analysis, 18: 164-173.

Leuz, C., Nanda, D. and Wysocki, P.D. (2003) 'Earnings management and investor protection: an International comparison', Journal of Financial Economics, 69: 505-527.

Othman, H. B. and Zeghal, D. (2006) 'A study of earnings-management motives in the AngloAmerican and Euro-Continental accounting models: The Canadian and French cases', The International Journal of Accounting, 41(4): 406-435.

Peasnell, K. V. Pope, P.F. and Young, S. (2000) 'Accrual management to meet earnings targets: U.K. evidence pre-and post-Cadbury’, British Accounting Review 32: 415-445.

Reverte, C. 2008 'Institutional differences in EU countries and their relationship with earnings management differences: Implications for the pan-European stock market', Journal of Accounting \& Organizational Change, 4 (2): 182-200.

Rodríguez - Pérez, G. and Hemmen, S. (2010) 'Debt, diversification and earnings management', Journal of Accounting and Public Policy, 29(2): 138-159.

Sankar, M.R. and Subramanyam, K.R. (2001) 'Reporting Discretion and Private Information Communication through Earnings', Journal of Accounting Research, 39(2): 365-386.

Schipper, K. (1989) 'Commentary on Earnings Management', Accounting Horizons, 3(4): 91-102

Seba Grubišić, M. (2013) 'Financing policies of Croatian publicly listed firms', UTMS Journal of Economics, 4(2): 127-141.

Suda, K. and Shuto, A. (2005) 'Earnings Management to Avoid Earnings Decreases and Losses: Empirical Evidence from Japan'. Working paper available at SSRN: http://ssrn.com/abstract=701525 orhttp://dx.doi.org/10.2139/ssrn.701525 (Accessed: 1 September 2014) 
Watts, R.L. and Zimmerman, J.L. (1978) 'Towards a Positive Theory of the Determination of Accounting Standards', The Accounting Review, 53(1): 112-134.

Watts, R.L. and Zimmerman, J.L. (1990) 'Positive Accounting Theory: A Ten Year Perspective', The Accounting Review, 65(1): 131-156.

Wright, C. J., Shaw, J. R., \& Guan, L. (2006) 'Corporate governance and investor protection: Earnings management in the U.K. and U.S.', Journal of International Accounting Research, 5(1): 25-40. 


\section{Table 1: Descriptive statistics}

\section{Panel A}

Descriptive statistics for the earnings level sample

\begin{tabular}{|c|c|c|c|c|c|c|c|c|}
\hline & $N$ & Mean & $\begin{array}{l}\text { Std. } \\
\text { Dev. }\end{array}$ & $25 \%$ & $50 \%$ & $75 \%$ & Min & Max \\
\hline $\mathrm{E}_{\mathrm{t}}$ & 1327 & -0.006 & 0.104 & -0.035 & 0.003 & 0.029 & -0.538 & 1.493 \\
\hline MJ_NDE & 1160 & -0.056 & 0.601 & -0.142 & -0.036 & 0.036 & -8.806 & 16.670 \\
\hline PA_NDE & 1160 & -0.015 & 0.701 & -0.122 & -0.024 & 0.055 & -8.116 & 16.677 \\
\hline
\end{tabular}

Panel B

Descriptive statistics for the earnings change sample

\begin{tabular}{|c|c|c|c|c|c|c|c|c|}
\hline & $N$ & Mean & $\begin{array}{c}\text { Std. } \\
\text { Dev. }\end{array}$ & $25 \%$ & $50 \%$ & $75 \%$ & Min & $\operatorname{Max}$ \\
\hline$\Delta \mathrm{E}_{\mathrm{t}}$ & 1198 & 0.002 & 0.136 & -0.020 & 0.000 & 0.016 & -1.106 & 1.681 \\
\hline$M J \_N D \Delta E_{t}$ & 974 & 0.039 & 0.865 & -0.108 & 0.012 & 0.167 & -16.463 & 16.716 \\
\hline$P A \_N D \Delta E_{t}$ & 974 & -0.012 & 0.939 & -0.159 & -0.009 & 0.117 & -16.455 & 16.723 \\
\hline
\end{tabular}

$\mathrm{E}_{\mathrm{t}}=$ Earnings scaled by opening total assets in year $\mathrm{t}$;

MJ_NDE $E_{t}=$ Non-discretionary earnings, scaled by opening total assets in year $\mathrm{t}$, measured as earnings in year $\mathrm{t}$ less discretionary accruals in year $t$, estimated with the modified Jones model in year $t$;

PA_NDE $E_{t}=$ Non-discretionary earnings, scaled by opening total assets in year $t$, measured as earnings in year $t$ less discretionary accruals in year $\mathrm{t}$, estimated with the performance-adjusted model in year $\mathrm{t}$;

$\Delta \mathrm{E}_{\mathrm{t}}=$ Change in earnings scaled by opening total assets in year $\mathrm{t}-1$;

MJ_ND $\Delta E_{t}=$ Non-discretionary change in earnings scaled by opening total assets, in year $\mathrm{t}-1$, measured as change in earnings less discretionary accruals, estimated with the modified Jones model in year $\mathrm{t}-1$;

PA_ND $\Delta E_{t}=$ Non-discretionary change in earnings scaled by opening total assets, in year $\mathrm{t}-1$, measured as change in earnings less discretionary accruals, estimated with the performance-adjusted model in year $\mathrm{t}-1$. 
Figure 1: The distribution of annual net income scaled by opening total assets in year $t$ for the period 2006-2013 $\left(\mathbf{E}_{\mathrm{t}}\right)$

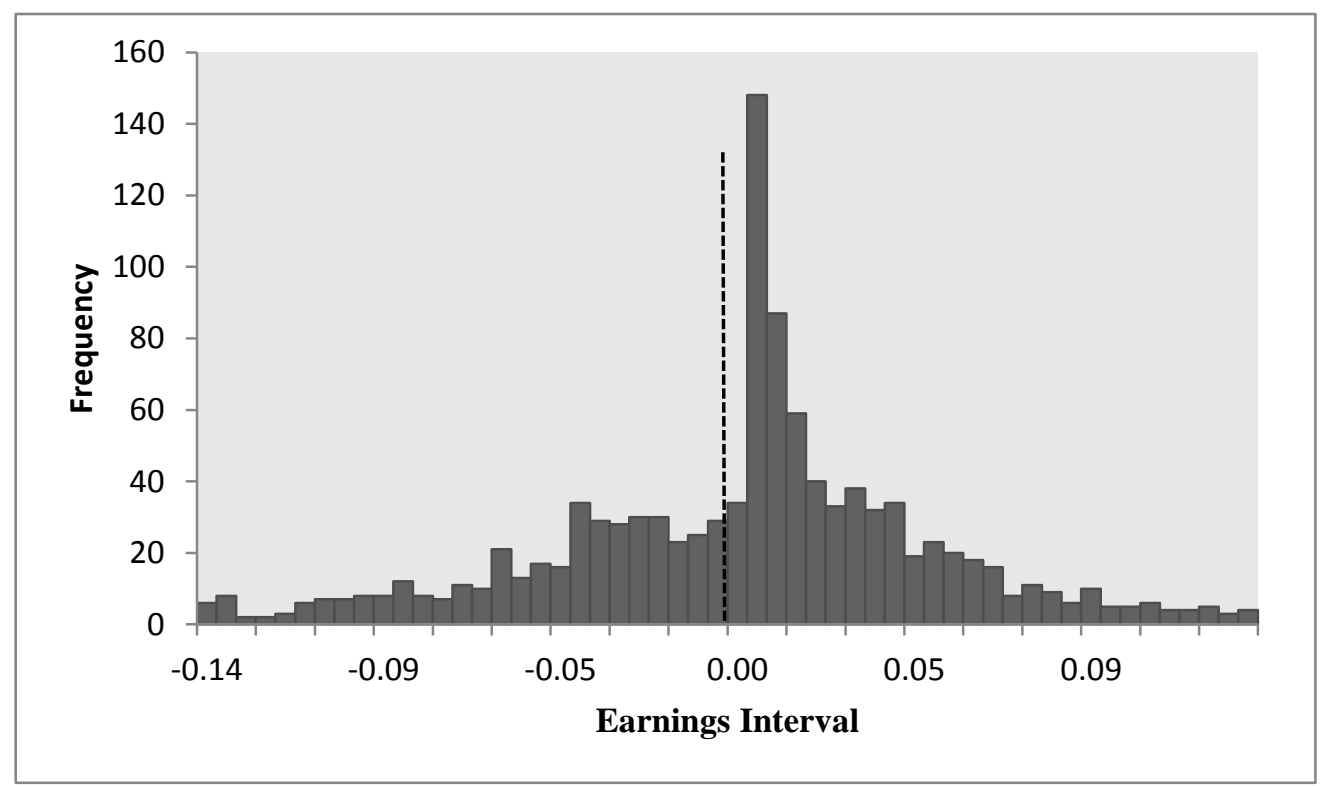

Notes: The distribution interval widths are 0.005 and the location of zero on the horizontal axis is marked by the dashed line. The first interval to the right of zero contains all the observations that are $>0 \leq 0.005$. The vertical axis labelled frequency represents the number of observations in each scaled earnings interval. The outliers of the annual earnings scaled by opening total assets in year $\mathrm{t}$ are not presented in the graph. 
Figure 2: The distribution of annual non-discretionary earnings scaled by opening total assets in year $\mathbf{t}$ estimated with the Modified Jones model for the period 2006-2013 (MJ_NDEt)

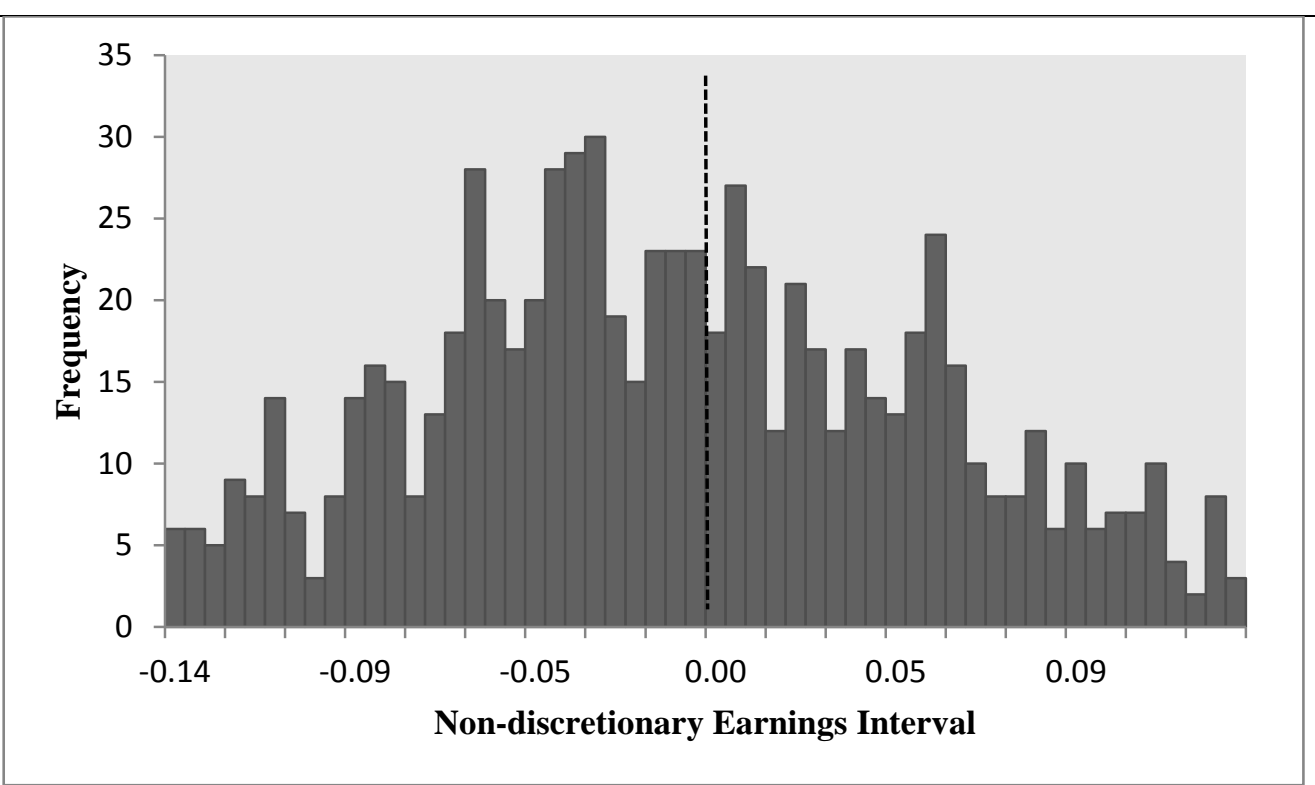

Notes: The distribution interval widths are 0.005 and the location of zero on the horizontal axis is marked by the dashed line. The first interval to the right of zero contains all the observations that are $>0 \leq 0.005$. The vertical axis labelled frequency represents the number of observations in each non-discretionary scaled earnings interval. The outliers of the annual non-discretionary earnings scaled by opening total assets in year $\mathrm{t}$ are not presented in the graph. 
Figure 3: The distribution of annual non-discretionary earnings scaled by opening total assets in year $t$ estimated with the performance-adjusted model for the period 2006-2013 (PA_NDEt)

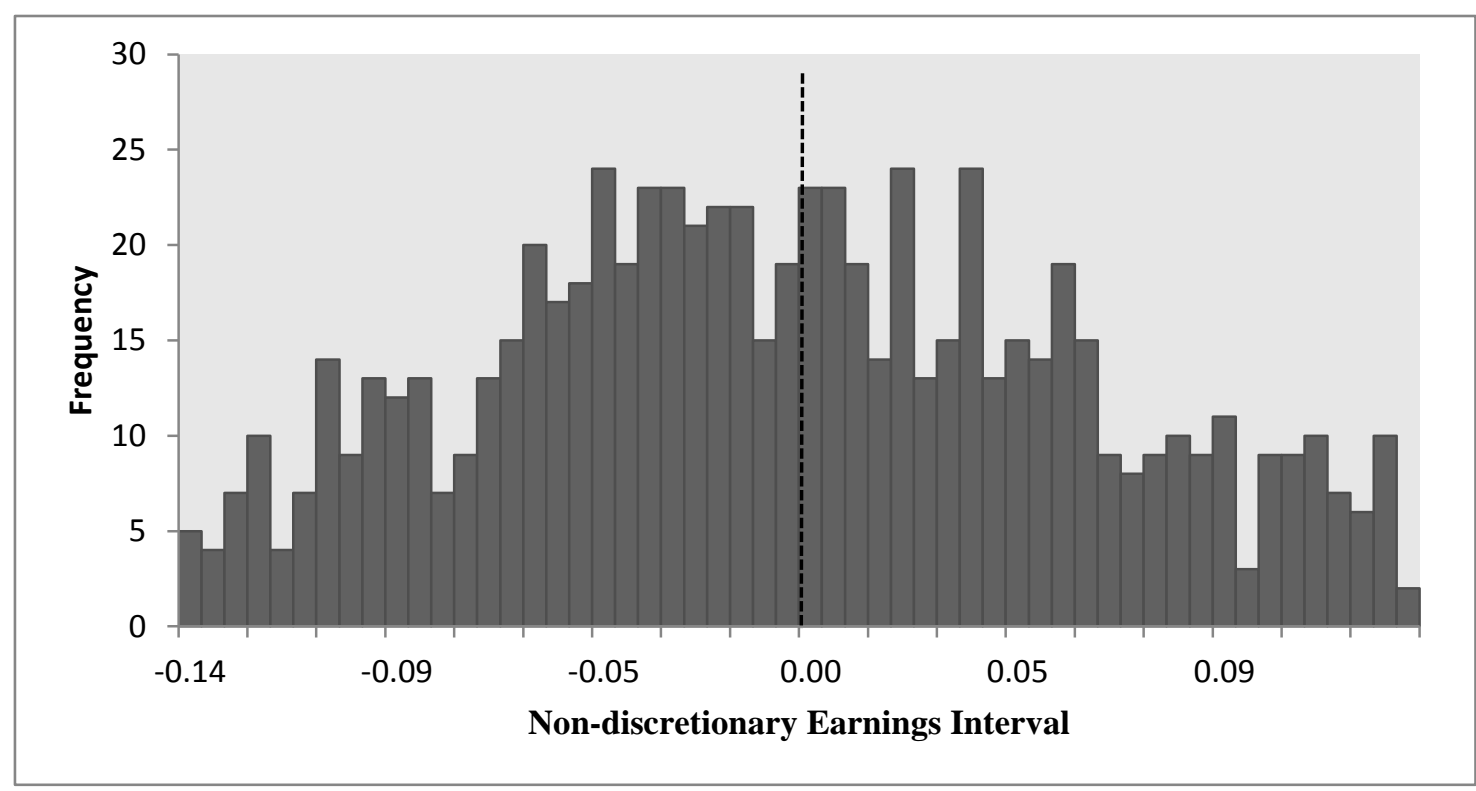

Notes: The distribution interval widths are 0.005 and the location of zero on the horizontal axis is marked by the dashed line. The first interval to the right of zero contains all the observations that are $>0 \leq 0.05$. The vertical axis labelled frequency represents the number of observations in each non-discretionary scaled earnings interval. The outliers of the annual non-discretionary earnings scaled by opening total assets in year $t$ are not presented in the graph. 
Figure 4: The distribution of change in annual net income scaled by opening total assets in year $\mathrm{t}-1$ for the period $2007-2013\left(\Delta \mathrm{E}_{\mathrm{t}}\right)$

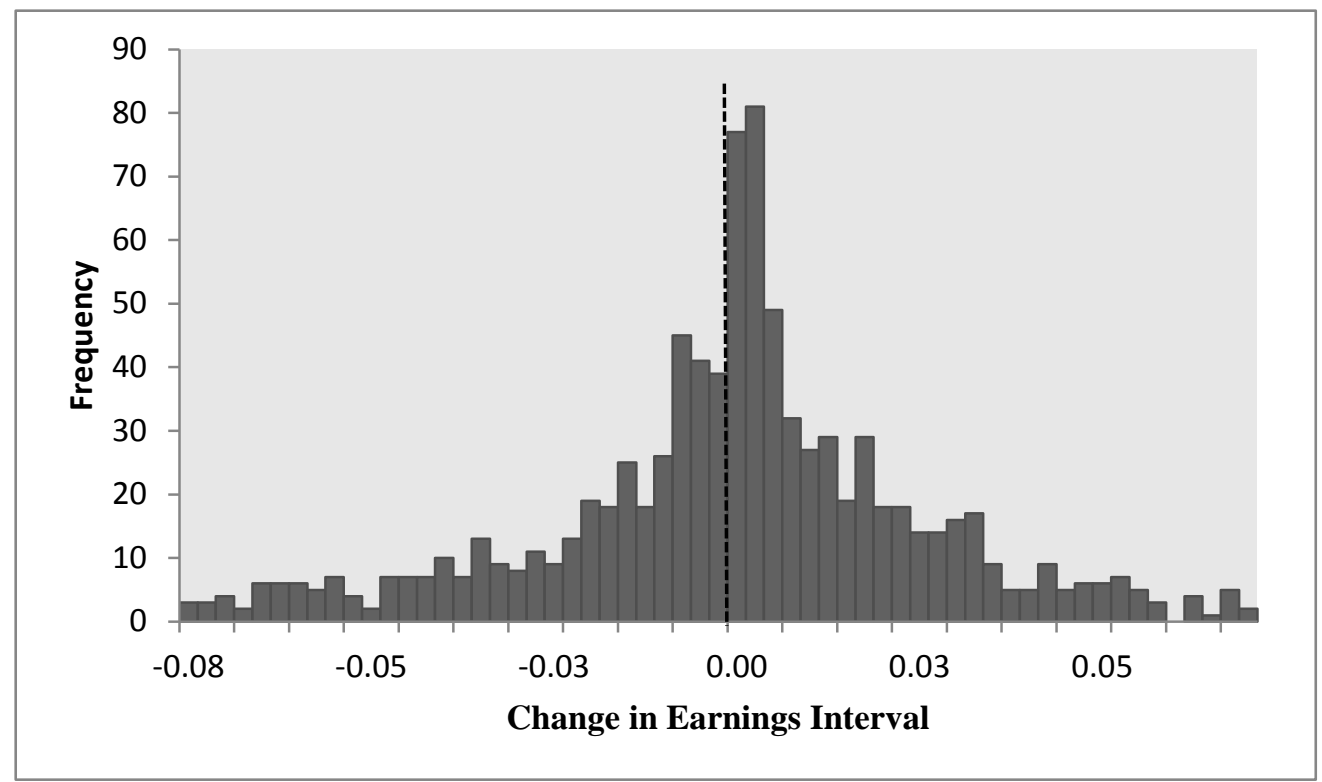

Notes: The distribution interval widths are 0.0025 and the location of zero on the horizontal axis is marked by the dashed line. The first interval to the right of zero contains all the observations that are $>0 \leq 0.0025$. The vertical axis labelled frequency represents the number of observations in each scaled earnings change interval. The outliers of changes in earnings scaled by opening total assets in year $\mathrm{t}-1$ are not presented in this graph. 
Figure 5: The distribution of non-discretionary change in earnings scaled by opening total assets in year $t-1$ estimated with the Modified Jones model for the period 2007-2013 (MJ_ND $\left.\Delta \mathbf{E}_{\mathbf{t}}\right)$

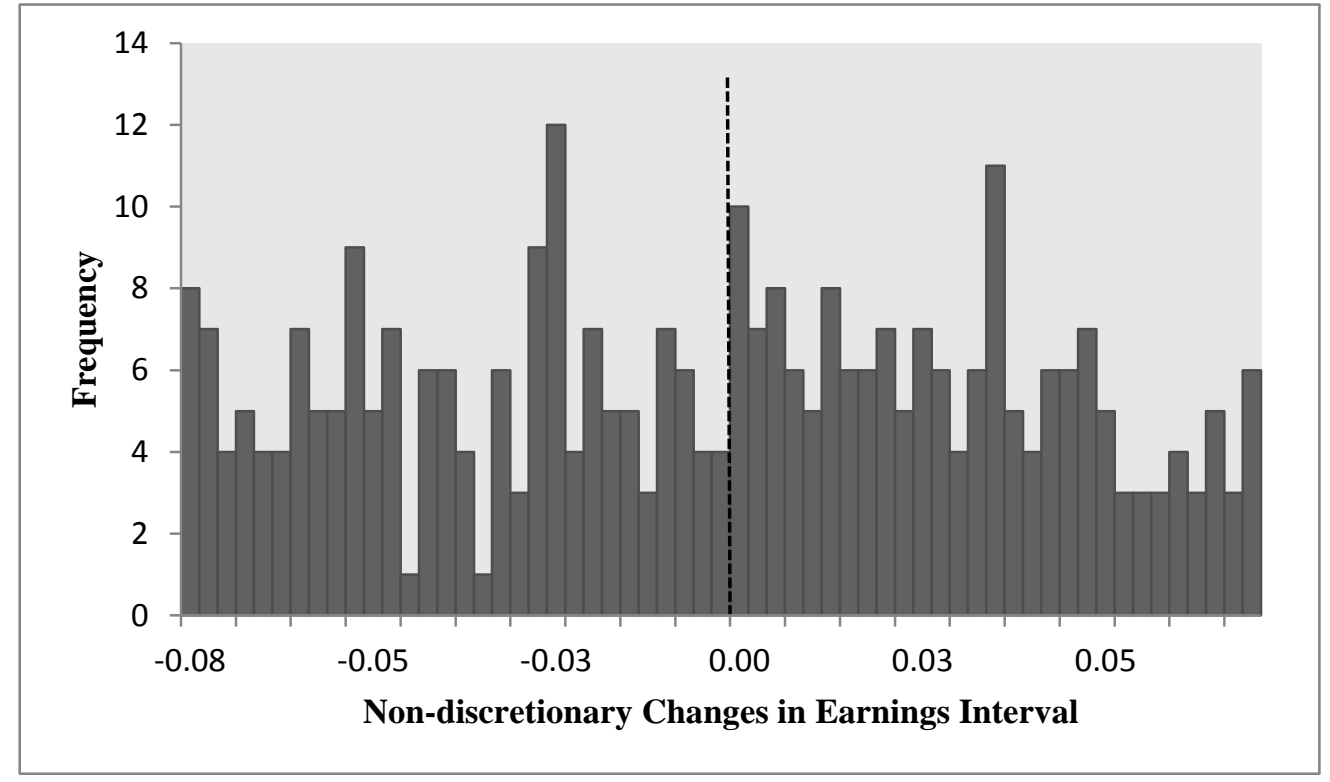

Notes: The distribution interval widths are 0.0025 and the location of zero on the horizontal axis is marked by the dashed line. The first interval to the right of zero contains all the observations that are $>0 \leq 0.0025$. The vertical axis labelled frequency represents the number of observations in each non-discretionary scaled earnings change interval. The outliers of changes in non-discretionary earnings scaled by opening total assets in year t-1 are not presented in this graph. 
Figure 6: The distribution of non-discretionary change in earnings scaled by opening total assets in year $\mathrm{t}-1$ estimated with the performance-adjusted model for the period 2007-2013 (PA_NDAEt)

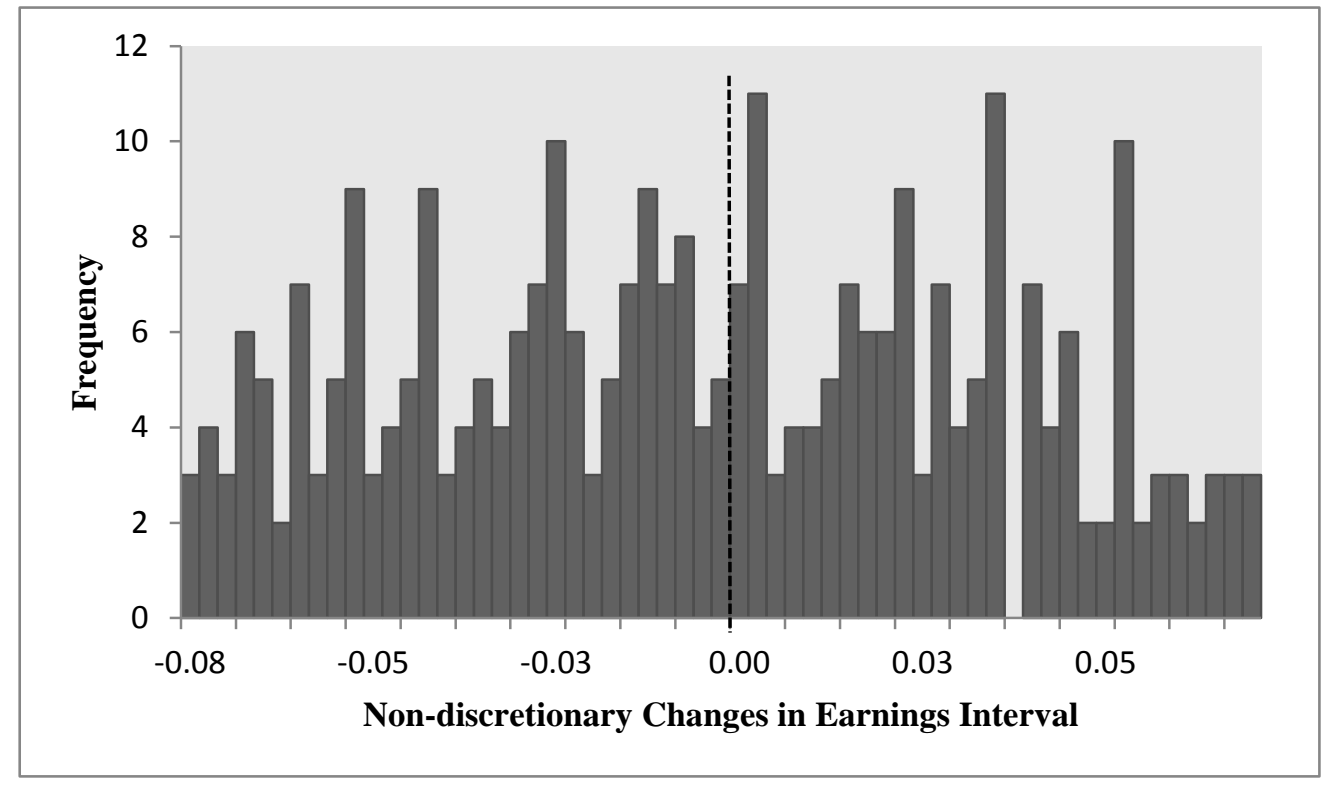

Notes: The distribution interval widths are 0.0025 and the location of zero on the horizontal axis is marked by the dashed line. The first interval to the right of zero contains all the observations that are $>0 \leq 0.0025$. The vertical axis labelled frequency represents the number of observations in each non-discretionary scaled earnings change interval. The outliers of changes in non-discretionary earnings scaled by opening total assets in year $\mathrm{t}-1$ are not presented in this graph. 